\title{
A DESCOISIFICAÇÃO DOS ANIMAIS NO PARADIGMA DO ESTADO SOCIOAMBIENTAL DE DIREITO: O PROJETO DE LEI DO SENADO 351/2015
}

\author{
ANIMALS NO LONGER BEING CONSIDERED THINGS IN THE PARADIGMA OF \\ SOCIO-ENVIRONMENTAL LAW: THE SENATE LAW PROJECT 351/2015
}

\author{
${ }^{1}$ Jose Carlos Machado Junior \\ ${ }^{2}$ Paula Vieira Teles
}

\section{RESUMO}

O Projeto de Lei do Senado número 315/2015, dispondo que os animais não são coisas, é objeto de estudo nesse artigo sob a ótica do Estado Socioambiental de Direito. A hipótese trabalhada é que o nova ordem jurídica inaugurada com a Constituição de 1988 determina a máxima proteção ambiental e a revisão da equiparação dos animais a coisas ou objetos. Para fins de comparação são citados os artigos do Código Civil Francês, do Código Civil Alemão e do Código Civil Suíço que tratam do mesmo objeto. A conclusão é que o projeto de lei sob análise caso aprovado representará um avanço importante, mas ainda insuficiente para cumprir as regras e princípios de proteção ambiental no paradigma do Estado Socioambiental de Direito. O método dedutivo é usado com pesquisa bibliográfica e a análise da legislação brasileira e estrangeira.

Palavras-chave: Direito dos animais, Estado socioambiental de direito, Descoisificação dos animais, Projeto de lei do senado 351/2015

\begin{abstract}
The Senate Law Project number 315/2015, that advocates that animals are not things, and theme of study in this article under the optic of the socio-environmental law estate. The hypothesis developed is that the new juridic order launched with the Constitution of 1988 determines the maximum environmental protection and the revision of the equivalency of animals and things or objects. for comparative reasons are quoted the articles of the french civil code, of the german civil code and the swiss civil code which treat the same matter. The conclusion is that the law project under analysis if approved will represent an important, but still insufficient improvement to follow the rules and principles of environmental protection in the paradigma of the socio-environmental law estate. The deductive method is used with bibliography and the analysis of brazilian and foreign law.
\end{abstract}

Keywords: Animal rights, Socio-environmental law estate, Animals no longer being considered things, The senate law project 351/2015

\footnotetext{
${ }^{1}$ Mestre em Direito Ambiental e Sustentabilidade pela Escola Superior Dom Helder Câmara, ESDHC, Belo Horizonte - MG (Brasil). Professor da Escola Superior Dom Helder Câmara - ESDHC, Belo Horizonte - MG (Brasil). E-mail: josecarlosmachadojunior@gmail.com

${ }^{2}$ Mestre em Direito pela Escola Superior Dom Helder Camara - ESDHC. Professora do Centro Universitário de Formiga - UNIFORMG, Formiga - MG (Brasil). E-mail: paulavteles@ yahoo.com.br
} 


\section{INTRODUÇÃO}

Esse artigo tem como objeto a análise, no paradigma do estado socioambiental de direito, do projeto de lei do Senado número 351, de 2015, que altera o Código Civil brasileiro incluindo dispositivo que expressamente dispõe que os animais não são coisas, seguindo tendência já incorporada no Código Civil Francês e Alemão entre outros.

O debate sobre a natureza jurídica dos animais não-humanos e sobre a possibilidade deles serem titulares de direito evoluiu nas últimas décadas, amparado em teorias diversas, muita em sentidos diferentes, provocando alterações em vários ordenamentos jurídicos.

Essa discussão também é observado no texto constitucional brasileiro que prevê a competência da União para legislar sobre a caça e a pesca, no seu artigo 24, VI e, no artigo 225 do mesmo texto, determina a proteção da fauna, vedando o tratamento cruel ou o manejo que possa promover a extinção de espécies.

Essas disposições revelam, em primeira análise, que a Constituição Federal acolheu a corrente do bem-estar animal (animal welfare) já que veda o tratamento cruel e a extinção de espécies, mas prevê a caça, sem restringir essa atividade as situações de necessidade alimentar.

A vedações de tratamento cruel e de extinção de espécies são compreendidos por parte da doutrina, de modo mais tradicional, como uma regra de proteção aos homens, pela indignação e repulsa que podem sentir diante de tratamentos cruéis impostos a animais ou pela discordância quanto a indignidade da conduta de se rebaixar para afligir a outros seres um sofrimento além do necessário.

De de qualquer modo, a legislação infraconstitucional brasileira não se afasta do entendimento da coisificação dos animais. Destaca-se o Código Civil brasileiro que em vários dos seus artigos concebe o animal como um objeto ou uma coisa.

A proposta contida no Projeto de Lei do Senado 315, de 2015, preenche uma lacuna no sistema jurídico brasileiro, já que inexistente nesse sistema qualquer dispositivo que inequivocamente ampare a tese de que os animais não são coisas. Ao contrário, a garantia constitucional do direito de propriedade, acrescido da disposição sobre a sua função social, amparam a existência de regras jurídicas que restrigem ou limitam o manejo, tratamento e utilização dos animais, mas não os descaracterizam como coisas. 


\title{
2 O ESTADO SOCIOAMBIENTAL DE DIREITO
}

Esclarece Romeu Thomé ${ }^{1}$ que a constitucionalização do direito ao meio ambiente equilibrado é considerada uma das mais relevantes conquistas do final do século $\mathrm{XX}$, com influências em mais mais de 40 países após a Conferência de Estocolmo de 1972.

O desenvolvimento científico do direito ao meio ambiente e a sua fundamentalização transformaram o tema do meio ambiente que "passou a ser visto como mais democrático dentre os temas de direitos humanos. Democrático no sentido de que alcança a todos os indivíduos do planeta, ricos ou pobres, oprimidos ou opressores, proprietários ou não proprietários, governantes ou governados."2

O debate sobre os direitos sociais passaram a incluir a necessidade de se garantir um mínimo existencial fático, conforme alerta Romeu Thomé ${ }^{3}$ :

\begin{abstract}
Não há que se falar em garantia e manutenção de direitos sociais, por exemplo, caso não haja acesso à água potável, caso os alimentos quimicamente contaminados causem graves danos à saúde, caso moradias residenciais sejam construídas sobre solos contaminados, caso eventos climáticos extremos assolem de uma só vez toda a população de determinada região, interrompendo vidas.
\end{abstract}

Informam Heline Sivini Ferreira e José Rubens Morato Leite ${ }^{4}$ que o Estado de Direito evoluiu para um Estado de Direito Ambiental em razão das consequências ecológicas da crise ambiental. Essa evolução é registrada no ordenamento jurídico de vários Estados.

José Rubens Morato e Patryck de Araújo Ayala definem o Estado de Direito Ambiental, "como o produto de novas reivindicações fundamentais do ser humano e particularmente pela ênfase que confere à proteção do meio ambiente." 5

\footnotetext{
1 THOMÉ, Romeu. O princípio da vedação de retrocesso socioambiental no contexto da sociedade de risco. Salvador: Juspodivm, 2014. p. 41-43.

2 RIBEIRO, Luiz Gustavo Gonçalves; MACHADO JÚNIOR, José Carlos. A ambientalização do direito penal: a tutela do ambiente pela terceira via. In: CUNHA, Belinda Pereira da; ALBURQUEQUE, Letícia; SOUZA, Leonardo da Rocha de (coords.) Direito Ambiental III. Florianópolis: FUNJAB, 2014, p. 378. Disponível em: <http://bit.ly/1x8iPCk> Acesso em: 16 ago. 2015.

3 THOMÉ, Romeu. O princípio da vedação de retrocesso socioambiental no contexto da sociedade de risco. Salvador: Juspodivm, 2014. p. 53.

4 FERREIRA, Heline Sivini Ferreira; LEITE, José Rubens Morato. A expressão dos objetivos do estado de direito ambiental na Federal de 1988. In: LEITE, José Rubens Morato; FERREIRA, Heline Sivini; CAETANO, Matheus Almeida (orgs.). Repensando o estado de direito ambiental. Florianópolis: Fundação Boiteux, 2012, p. 41.

5 LEITE, José Rubens Morato; AYALA, Patryck de Araújo. Dano ambiental: do individual ao coletivo extrapatrimonial. São Paulo: Editora Revista dos Tribunais, 2010, p. 37.
} 
O debate ambiental, ensina José Afonso da Silva ${ }^{6}$, não está restrito na Constituição de 1988 a um capítulo específico, ele se relaciona com temas constitucionais fundamentais e permeia todo o seu texto:

A Constituição de 1988 foi, portanto, a primeira, entre nós, a tratar deliberadamente da questão ambiental. Pode-se dizer que ela é uma Constituição eminentemente ambientalista. Assumiu o tratamento da matéria em termos amplos e modernos. Traz um capítulo específico sobre o meio ambiente, inserido no título da ordem social. Mas a questão permeia todo o seu texto, correlacionada com os temas fundamentais da ordem constitucional.

Rafaela Emilia Bortolini e Patryck de Araújo Ayala ${ }^{7}$ sintetizam as características do modelo de estado socioambiental decorrentes da Constituição: "permanente construção de um Estado com contornos de sensibilidade ecológica, numa leitura de integração - jamais de exclusão e conflituosidade - das múltiplas realidades e valores, entre os quais o ambiente."

Partindo do reconhecimento do meio ambiente ecologicamente equilibrado como direito fundamental de terceira dimensão, Romeu Thomé ${ }^{8}$ prefere a expressão "Estado Democrático Socioambiental de Direito" para designar o Estado brasileiro que após a Constituição de 1988 passa a reunir as conquistas do Estado Liberal e as do Estado Social, no que diz respeito às exigências de proteção ambiental.

Esclarece o autor que o modelo de Estado Social está ultrapassado pelo modelo de Estado Socioambiental, considerando-se a relação entre meio ambiente equilibrado e a dignidade da pessoa humana. ${ }^{9}$

A expressão "Estado de Direito Ambiental - EDA" é preferida por José Rubens Morato Leite e Matheus Almeida Caetano que a consideram “versão esverdeada e atualizada dos modelos de Estado Liberal e Social". ${ }^{10}$

Os autores destacam que a evolução do Estado Liberal para o Social, e desse para o Estado Ambiental, não implicou em uma sobreposição de direitos, mas em uma incorporação. Esclarecem que o Estado Liberal e o Estado Social ignoram o meio ambiente, que passa a ser,

\footnotetext{
6 SILVA, José Afonso da. Fundamentos constitucionais da proteção ambiental. In: DAIBERT, Arlindo (org). Direito Ambiental Comparado. Belo Horizonte: Fórum, 2008, p. 83.

7 BORTOLINI, Rafaela Emilia; AYALA, Patryck de Araújo. In: PADILHA, Norma Sueli; FIORILLO, Celso Antonio Pacheco; CAMPELlO, Livia Gaigher Bosio (orgs.). Direito ambiental I. Florianópolis: FUNJAB, 2013, p. 68-90. Disponível em: <http://bit.ly/1U8tmWf> Acesso em: 01 ago. 2015.

8 THOMÉ, Romeu. O princípio da vedação de retrocesso socioambiental no contexto da sociedade de risco. Salvador: Juspodivm, 2014. p. $46-53$.

9 Ibidem

10 LEITE, José Rubens Morato; CAETANO, Matheus Almeida. Breves Reflexões sobre os Elementos do Estado de Direito Ambiental Brasileiro. In: LEITE, José Rubens Morato; FERREIRA, Heline Sivini; CAETANO, Matheus Almeida (org). Repensando o estado de direito ambiental. Florianópolis: Fundação Boiteux, 2012, p. 81.
} 
no Estado de Direito Ambiental o quarto elemento, revolucionando a teoria clássica do Estado

e, como consequência, a teoria dos direitos fundamentais. ${ }^{11}$

O EDA pode ser considerado como uma versão esverdeada e atualizada dos modelos de Estado Liberal e Social, pois além de proteger os direitos individuais (primeira geração) e sociais (segunda geração), acaba por incorporar os direitos difusos ou de terceira geração, sem quaisquer sobreposições entre as três categorias de direitos fundamentais. Além disso, em se considerando os três lemas da Revolução Francesa (liberdade, igualdade e fraternidade) pode-se entrever uma simetria deles com os Estados Liberal, Social e Ambiental, nos moldes propugnados por Bobbio, Fensterseifer, Häberle, Nunes Junior e Pureza. Contudo, deve-se salientar que no EDA os princípios políticos da liberdade e da igualdade não são ignorados nem mitigados, simplesmente sofrem eles, conjuntamente com o da fraternidade, uma reformulação de cunho ecológico.

\section{Para Rafaela Emilia Bortolini e Patryck de Araújo Ayala o modelo de Estado}

Socioambiental é o que mais se adequa aos problemas ambientais da atualidade:

Como destacado alhures, o modelo de Estado Socioambiental afigura-se como o mais adequado para enfrentar os problemas ambientais da contemporaneidade. Por seu viés de integração entre direitos fundamentais e de aproximação de múltiplas realidades, sem implicar numa escolha de prevalência ou preponderância de qualquer delas, apresenta-se como o modelo estatal de maior sensibilidade e compatível com um projeto de vida digna e com qualidade às presentes e futuras gerações. ${ }^{12}$

Norma Sueli Padilha enfatiza a necessidade de uma nova abordagem e leitura do ordenamento jurídico ambiental com a constitucionalização do meio ambiente e o salto paradigmático da constitucionalidade ambiental:

Na verdade, a Carta Constitucional atual, ao adotar a constitucionalização do meio ambiente, dá um salto em direção a um novo paradigma da constitucionalidade ambiental que determina toda uma nova abordagem e leitura do ordenamento jurídico ambiental, pois não mais coloca a natureza em segundo plano, nem desconsidera sua importância, não só para a sadia qualidade de vida de todos, mas também como ser autônomo, digno de respeito e consideração em si e por si mesma. Trata-se de uma grande inovação no Direito Constitucional brasileiro, que abandona o tratamento jurídico do meio ambiente, por meio de legislações esparsas e sem sistematização, caracterizadas por uma conotação civilista e patrimonialista, inaugurando um novo modelo de normatividade jus ambiental, centrada na Constituição e numa abordagem nova, de proteção e responsabilização. ${ }^{13}$

11 Ibidem, p. 82.

12 BORTOLINI, Rafaela Emilia; AYALA, Patryck de Araújo. In: PADILHA, Norma Sueli; FIORILLO, Celso Antonio Pacheco; CAMPELlO, Livia Gaigher Bosio (orgs.). Direito ambiental I. Florianópolis: FUNJAB, 2013, p. 68-90. Disponível em: <http://bit.ly/1U8tmWf> Acesso em: 01 ago. 2015.

${ }^{13}$ PADILHA, Norma Sueli. O Compromisso Constitucional Brasileiro com a Sustentabilidade Ambiental. Disponível em: <http://bit.ly/1pBxstd> Acesso em: 01 ago. 2015. 
No mesmo sentido, Haide Maria Hupffer e Roberto Naime ${ }^{14}$, ao apontar o fenômeno do esverdeamento da Constituição resultando, nas palavras de Édis Milaré ${ }^{15}$, no surgimento de uma Constituição verde.

A fundamentalidade do direito ao meio ambiente já foi reconhecida pelo Supremo Tribunal Federal e pelo Superior Tribunal de Justiça, como ensina José Adércio Sampaio ${ }^{16}$, indicando os julgamentos do RE 134.297-SP e do MS 22.164-SP, em 1995, relator em ambos o Ministro Celso de Mello, como os pioneiros nesse reconhecimento expresso.

Patryck de Araújo Ayala observa a necessidade de se conjugar os dois acórdãos para uma compreensão completa das características do direito ao meio ambiente ecologicamente equilibrado reconhecidas pelo Supremo Tribunal Federal:

\begin{abstract}
Conquanto o julgamento do RE 134.297-8/SP tenha inaugurado a afirmação constitucional do direito fundamental ao meio ambiente, o desenvolvimento de seu significado diferenciado somente foi realizado no julgamento do MS 22.164/DF, no qual, pela primeira vez, o STF reconheceria expressamente características essenciais do bem ambiental, tal como proposta pela Constituição brasileira, quais sejam: a) a repartição de responsabilidade no exercício desses deveres; b) a relação estabelecida entre a sua concretização e os deveres atribuídos aos Poderes Públicos e à coletividade; $\mathrm{e}$, sobretudo, c) a titularidade compartilhada de interesses sobre o bem, que alcançam inclusive as futuras gerações. ${ }^{17}$
\end{abstract}

Em 2012, no julgamento da ADI 4029 - AM, relator o Ministro Luiz Fux, o Tribunal Pleno do Supremo Tribunal Federal ratificou a fundamentalização do direito ao meio ambiente ecologicamente equilibrado: "Deveras, a proteção do meio ambiente, direito fundamental de terceira geração previsto no art. 225 da Constituição, restaria desatendida caso pudessem ser questionados os atos administrativos praticados por uma autarquia em funcionamento desde 2007." ${ }^{\prime 18}$

Em março de 2015, no julgamento do agravo regimental no recurso extraordinário 796.347, relator o Ministro Celso de Mello, a segunda turma do Supremo Tribunal Federal,

\footnotetext{
14 HUPFFER, Haide Maria; NAIME, Roberto. Vocação de diálogo do artigo 225 da Constituição Federal no conflito ambiental. In: Revista veredas do direito. Belo Horizonte: Escola Superior Dom Helder Câmara, v. 9, n. 17, 2012, p. 222. Disponível em: <http://bit.ly/1zspeHN> Acesso em: 16 ago. 2015.

15 MILARÉ, Édis, Direito do ambiente: a gestão ambiental em foco: doutrina, jurisprudência, glossário. 7. ed. São Paulo: Editora Revista dos Tribunais, 2011, p. 184.

16 SAMPAIO, José Adercio Leite. Responsabilidade Ambiental e Ação Civil Pública. In SOARES Junior, Jarbas; ALVARENGA, Luciano José (Cord.). In: Direito Ambiental no STJ. Belo Horizonte: Del Rey, 2010, p. 158-

159.

17 AYALA, Patrick de Araújo. Constitucionalização do ambiente e ecologização da Constituição brasileira. In: CANOTILHO, José Joaquim Gomes, LEITE, José Rubens Morato (orgs.). Direito Constitucional Ambiental Brasileiro. 5. ed. São Paulo: Saraiva, 2012 , p. 418.

18 BRASIL, Supremo Tribunal Federal. Ação Direta de Inconstitucionalidade 4029. Rel. Min. Luiz Fux, j. 08.03.2012, Dje 26.06.2012. Disponível em: <http://bit.ly/1uuuCdA> Acesso em: 16 ago. 2015.
} 
aborda a natureza do direito ao meio ambiente destacando a sua essencialidade:

\begin{abstract}
Cabe acentuar, desde logo, que a essencialidade do direito ao meio ambiente fez com que o legislador constituinte impusesse, ao Poder Público e à coletividade, o dever de defendê-lo e de preservá-lo para as presentes e futuras gerações (CF , art. 225), em ordem a legitimar a atuação do Ministério Público e do Poder Judiciário naquelas hipóteses em que os órgãos estatais, anomalamente, deixassem de respeitar o mandamento constitucional, frustrando-lhe, arbitrariamente, a eficácia jurídicosocial, seja por intolerável omissão, seja por qualquer outra inaceitável modalidade de comportamento governamental desviante. ${ }^{19}$
\end{abstract}

No mesmo voto, o Ministro relator destaca que os preceitos inscritos no artigo 225, da Constituição Federal, "traduzem, na concreção de seu alcance, a consagração constitucional, em nosso sistema de direito positivo, de uma das mais expressivas prerrogativas asseguradas às formações sociais contemporâneas" ${ }^{20}$

A fundamentalidade do direito ao meio ambiente ecologicamente equilibrado é reafirmada no acordão, que menciona a Declaração de Estocolmo sobre o Meio Ambiente (1972) e a Conferência das Nações Unidas sobre Meio Ambiente e Desenvolvimento (Rio/92) para concluir que a questão do meio ambiente passou a integrar a agenda internacional como um dos mais expressivos tópicos e que se reconheceu "ao gênero humano o direito fundamental à liberdade, à igualdade e ao gozo de condições de vida adequada, em ambiente que lhe permita desenvolver todas as suas potencialidades em clima de dignidade e de bemestar.“21

A previsão constitucional do direito ao meio ambiente ecologicamente equlibrado, especialmente no artigo 225 do texto constitucional brasileiro, elevou esse direito a condição de direito essencial e fundamental, conforme a doutrina e conforme a jurisprudência reiterada do Supremo Tribunal Federal.

Conforme Ribeiro e Machado, esse conjunto de normas constitucionais formam a base jurídica para o fenômeno da ambientalização do direito brasileiro:

\footnotetext{
19 BRASIL, Supremo Tribunal Federal. Agravo Regimental no Recurso Extraordinário RE 796347. Rel. Min. Celso de Mello, j. 24.03.2015, Dje 13.05.2015. Disponível em: <http://bit.ly/1hBEDT8> Acesso em: 01 ago. 2015.

20 Ibidem

21 BRASIL, Supremo Tribunal Federal. Agravo Regimental no Recurso Extraordinário RE 796347. Rel. Min. Celso de Mello, j. 24.03.2015, Dje 13.05.2015. Disponível em: <http://bit.ly/1hBEDT8> Acesso em: 01 ago. 2015.
} 


\begin{abstract}
O denominado esverdeamento da Constituição da República, desse modo, não deve ser compreendido apenas como um mandamento de proteção ambiental isoladamente considerado, mas, principalmente, como um celeiro de princípios concatenados e voltados à combinação entre o direito ao meio ambiente ecologicamente equilibrado e o direito ao desenvolvimento sustentável. A ideia de uma Constituição verde e a de uma consciência nacional ambiental formam a base de legalidade e de legitimação para um fenômeno jurídico que pode ser denominado de "ambientalização" do direito brasileiro, fenômeno que se apresenta como um novo paradigma jurídico, o paradigma ambiental. ${ }^{22}$
\end{abstract}

As transformações advindas da crise ambiental alteraram a estrutura jurídica dos Estados modernos e, no Brasil, com a Constituição de 1988, o direito ao meio ambiente ecologicamente equilibrado foi elevado a categoria de direito fundamental, com a criação de um sistema de proteção para preservá-lo para a atual e para as futuras gerações. Tais mutações alteraram o sistema jurídico brasileiro, permeando-o com princípios e regras ambientais, e transformando o estado brasileiro em um Estado Socioambiental de Direito.

\title{
3 A PRoteÇão Ambiental EFEtiva no ESTAdo Sociambiental de DIREITO
}

Consoante o disposto no artigo 225, da Constituição brasileira, incumbe ao Poder Público e a coletividade o dever de defender e preservar o meio ambiente para a atual e para as futuras gerações: "Todos têm direito ao meio ambiente ecologicamente equilibrado, bem de uso comum do povo e essencial à sadia qualidade de vida, impondo-se ao Poder Público e à coletividade o dever de defendê-lo e preservá- lo para a presente e futuras gerações.”. 23

Esse dever expresso, em um Estado Socioambiental de Direito e em um sistema jurídico ambientalizado, implica na máxima efetividade das regras de proteção ambiental.

A busca por uma interpretação e aplicação do direito constitucional e infraconstitucional que possibilite atingir a efetividade da proteção ambiental, para a presente e para as futuras gerações, deve ser assumida pelos intérpretes da Constituição e pelos operadores do direito como um dever constitucionalmente imposto, sob pena de se fazer letra morta o comando insculpido no artigo 225 do texto constitucional.

\footnotetext{
22 RIBEIRO, Luiz Gustavo Gonçalves; MACHADO JÚNIOR, José Carlos. A ambientalização do direito penal: a tutela do ambiente pela terceira via. In: CUNHA, Belinda Pereira da; ALBURQUEQUE, Letícia; SOUZA, Leonardo da Rocha de (coords.) Direito Ambiental III. Florianópolis: FUNJAB, 2014, p. 371-388. Disponível em: <http://bit.ly/1x8iPCk> Acesso em: 16 ago. 2015.

23 BRASIL. Constituição da República Federativa do Brasil. Disponível em: <http://bit.ly/ZChEh1> Acesso em: 17 ago. 2015.
} 
Esse é o magistério de Norma Sueli Padilha:

O compromisso constitucional de defender e preservar o direito ao equilíbrio do meio ambiente impõe aos vários intérpretes da Constituição, desde o cidadão, os órgãos estatais, as organizações não governamentais, a opinião pública, o papel de darlhe efetividade, de extrair da Constituição a concretização de tal comando. E, como decorrência do pleno exercício da cidadania, caberá aos seus representantes acionar o Poder Judiciário quando do descumprimento do compromisso constitucional, cabendo então aos intérpretes judiciais, atuando em prol da supremacia da vontade constitucional, dar efetividade ao tratamento constitucional conferido a proteção do meio ambiente. ${ }^{24}$

A busca pela efetividade da proteção ambiental deve ser conduzida por um pensamento holístico e sistêmico, na lição de Bruno Laskowski Staczuk e Heline Sivini Ferreira: “A adoção de um pensamento sistêmico, holístico, para a análise de sistemas é de extrema relevância.". ${ }^{25}$

Explica Antônio Herman Benjamin ${ }^{26}$ que a preocupação com a efetividade das normas de proteção ambiental levou o constituinte de 1988 a construir um sistema de proteção constitucional, para que a tutela ambiental não fosse deixada para a implementação por atuação infranconstitucional. A tutela ambiental, afirma, deve ser viabilizada através de instrumentos jurídicos também constitucionalizados, como a ação civil pública e a ação popular, além das várias espécies de sanções previstas no texto constitucional.

O autor destaca o trabalho do constituinte de 1988 que não deixou para o que chama de "destino retórico", a criação de normas que viabilizem a proteção efetiviva do meio ambiente ecologicamente equilibrado. ${ }^{27}$

Esclarece Benjamin ${ }^{28}$ que embora a Constituição de 1988, em matéria ambiental, tenha adotado o discurso e a linguagem da Declaração de Estocolmo e recebido influências de outras Constituições, especialmente a Espanhola, a Grega e a Portuguesa, não deixou de conceber os remédios jurídicos para os vários problemas ambientais brasileiros, aspecto no qual se destaca como um dos sistemas mais abrangente em matéria de proteção ambiental.

\footnotetext{
24 PADILHA, Norma Sueli. Fundamentos constitucionais do direito ambiental brasileiro. Rio de Janeiro: Elsevier, 2010 , p. 171.

25 STACZUK, Bruno Laskowski; FERREIRA, Heline Sivini. A dimensão social do estado de direito Ambiental.

In: LEITE, José Rubens Morato; FERREIRA, Heline Sivini; CAETANO, Matheus Almeida (org). Repensando o estado de direito ambiental. Florianópolis: Fundação Boiteux, 2012, p. 113.

26 BENJAMIN, Antonio Herman. Constitucionalização do ambiente e ecologização da constituição brasileira. In: CANOTILHO, José Joaquim Gomes, LEITE, José Rubens Morato (orgs.). Direito Constitucional Ambiental Brasileiro. 5. ed. São Paulo: Saraiva, 2012, p. 111.

27 Ibidem, p. 113.

28 Idem, Ibidem
} 


\title{
4 OS ANIMAIS NA LEGISLAÇÃO BRASILEIRA
}

O relacionamento entre os homens e os animais, ou entre os animais humanos e não humanos, denominações utilizadas pela doutrina, foi também influenciado pela ambientalização do direito no paradigma do Estado de Direito Socioambiental.

A Constituição Federal de 1988 trouxe para o centro dos debates atuais o alcance das normas de proteção aos animais, ao prever a vedação de tratamento cruel ao animais:

\begin{abstract}
Art. 225. Todos têm direito ao meio ambiente ecologicamente equilibrado, bem de uso comum do povo e essencial à sadia qualidade de vida, impondo-se ao Poder Público e à coletividade o dever de defendê-lo e preservá- lo para as presentes e futuras gerações.

$\S 1^{\circ}$ Para assegurar a efetividade desse direito, incumbe ao Poder Público:

VII - proteger a fauna e a flora, vedadas, na forma da lei, as práticas que coloquem em risco sua função ecológica, provoquem a extinção de espécies ou submetam os animais a crueldade. ${ }^{29}$
\end{abstract}

Apesar dos esforços de parte da doutrina, não há ainda um ramo jurídico autônomo a tratar das relações jurídicos que envolvam os animais. O direito animal, conceituado por Edna Cardozo Dias como “o conjunto de regras, leis e princípios que regulam a proteção do animal a fim de garantir a sua integridade física e moral, bem como a sua dignidade como animal não humano" 30 , ainda não adquiriu a necessária autonomia no direito brasileiro, apesar do argumento de que há suficiente teoria e embasamento para essa evolução. ${ }^{31}$

Nesse contexto, as relações entre os animais humanos e os animais não humanos são tratadas e disciplinadas por vários ramos do direito privado e do direito público, como o direito civil, o direito penal, o direito ambiental, o direito administrativo, o direito constitucional, o direito tributário, entre outros.

No Código Civil brasileiro o animal é considerado um objeto, uma coisa a ser preservada. Não prevê o Código Civil qualquer vedação ao tratamento cruel, como também não trata do manejo respeitoso e digno.

Os animais estão previstos em vários dispositivos do Código Civil ${ }^{32}$, sempre com o mesmo viés da coisificação:

\footnotetext{
29 BRASIL. Constituição Federal. Disponível em: 〈http://bit.ly/1bJYlGL> Acesso em: 10 ago. 2015.

${ }^{30}$ DIAS, Edna Cardozo. Teoria dos Direitos dos Animais. In: BIZAWU, Sébastien Kiwongui (org.). Direito dos Animais: desafios e perspectivas da proteção internacional. Belo Horizonte: Arraes Editores, 2015, p. 32-33.

31 DIAS, Edna Cardozo. Teoria dos Direitos dos Animais. In: BIZAWU, Sébastien Kiwongui (org.). Direito dos Animais: desafios e perspectivas da proteção internacional. Belo Horizonte: Arraes Editores, 2015, p. 33-35.

32 BRASIL. Lei n. 10.406, de 10 de janeiro de 2002. Insitui o Código Civil. Disponível em: 〈http://bit.ly/1drzx $5 j>$ Acesso em: 10 ago. 2015.
} 
Art. 936. O dono, ou detentor, do animal ressarcirá o dano por este causado, se não provar culpa da vítima ou força maior.

(...)

Art. 1.313. O proprietário ou ocupante do imóvel é obrigado a tolerar que o vizinho entre no prédio, mediante prévio aviso, para: (...)

II - apoderar-se de coisas suas, inclusive animais que aí se encontrem casualmente.

(...)

Art. 1.397. As crias dos animais pertencem ao usufrutuário, deduzidas quantas bastem para inteirar as cabeças de gado existentes ao começar o usufruto.

(...)

Os artigos 936, 1313 e 1397 tratam os animais e suas crias como bens, objeto do direito de propriedade, com um dono (art. 936) ou um proprietário (art. 1313).

Nos artigos 1442, 1444, 1445 e 1447, do Código Civil ${ }^{33}$, pode-se observar a equiparação dos animais a função de equipamentos, máquinas ou aparelhos:

Art. 1.442. Podem ser objeto de penhor:

(...)

$\mathrm{V}$ - animais do serviço ordinário de estabelecimento agrícola.

(...)

Art. 1.444. Podem ser objeto de penhor os animais que integram a atividade pastoril, agrícola ou de lacticínios.

Art. 1.445. O devedor não poderá alienar os animais empenhados sem prévio consentimento, por escrito, do credor.

Parágrafo único. Quando o devedor pretende alienar o gado empenhado ou, por negligência, ameace prejudicar o credor, poderá este requerer se depositem os animais sob a guarda de terceiro, ou exigir que se lhe pague a dívida de imediato.

Art. 1.446. Os animais da mesma espécie, comprados para substituir os mortos, ficam sub-rogados no penhor.

Art. 1.447. Podem ser objeto de penhor máquinas, aparelhos, materiais, instrumentos, instalados e em funcionamento, com os acessórios ou sem eles; animais, utilizados na indústria; sal e bens destinados à exploração das salinas; produtos de suinocultura, animais destinados à industrialização de carnes e derivados; matérias-primas e produtos industrializados.

(...)

§ 2o Tratando-se de venda de animais, os prazos de garantia por vícios ocultos serão os estabelecidos em lei especial, ou, na falta desta, pelos usos locais, aplicando-se o disposto no parágrafo antecedente se não houver regras disciplinando a matéria.

Não se considera existente no direito brasileiro, de forma autônoma, o direito dos animais. Os animais não humanos, equiparados a uma coisa, estão sujeitos a qualquer utilização pelos animais humanos. Podem, por exemplo, ser caçados e mortos por diversão e prazer.

A legislação penal de proteção ao meio-ambiente, Lei $n^{\circ} 9.605 / 98^{34}$, que dispõe sobre

\footnotetext{
33 BRASIL. Lei n. 10.406, de $\mathbf{1 0}$ de janeiro de 2002. Insitui o Código Civil. Disponível em: 〈http://bit.ly/1drzx5j> Acesso em: 10 ago. 2015.

34 BRASIL. Lei n. 9.605, de 12 de fevereiro de 1998. Dispõe sobre as sanções penais e administrativas derivadas de condutas e atividades lesivas ao meio ambiente, e dá outras providências. Disponível em: 〈http://bit.ly/1L6oaCf> Acesso em: 10 ago. 2015.
} 
as sanções penais e administrativas derivadas de condutas e atividades lesivas ao meio ambiente, ao prevê no seu artigo 32 o crime de abuso e maus-tratos de animais, não exclui a possibilidade da caça:

Art. 32. Praticar ato de abuso, maus-tratos, ferir ou mutilar animais silvestres, domésticos ou domesticados, nativos ou exóticos:

Pena - detenção, de três meses a um ano, e multa.

$\S 1^{\circ}$ Incorre nas mesmas penas quem realiza experiência dolorosa ou cruel em animal vivo, ainda que para fins didáticos ou científicos, quando existirem recursos alternativos.

Apesar do disparate da equiparação entre animais e uma massa falida, no exemplo de Alvaro Angelo Salles ${ }^{35}$, ao defender que os animais sejam considerados pessoas físicas não humanas, o ordenamento jurídico brasileiro ainda não contempla a descoisificação do animal.

Considerando-se os novos paradigmas impostos pelo Estado Socioambiental de Direito, a proteção e o reconhecimento dos animais na legislação brasileira é ainda insuficiente.

De fato, a interpretação que se faz da legislação sobre a caça, por exemplo, tema de competência legislativa da União, nos termos do artigo 24, VI da Constituição Federal, não leva em consideração a vedação de tratamento cruel contida no artigo 225, VII, do mesmo texto constitucional.

O tema é complexo e, como adverte Peter $\operatorname{Singer}^{36}$, não há uma resposta única para a indagação sobre a proibição ou o erro em se matar um animal, não apenas pela variedade de espécies animais, como também pela utilização, manejo e necessidade que atendem. Ademais, esclarece o autor, o conhecimento que a ciência proporciona sobre a natureza dos sentimentos e do intelecto dos animais é também uma variável a ser considerada para a elaboração de uma resposta.

Contudo, no Estado Sociambiental de Direito, não se pode conceber que a caça sem necessidade, por prazer ou diversão, não seja um tratamento cruel.

A caça, ainda que limitada e condicionada por normas infraconstitucionais, representa um ato de crueldade, pois vidas são sacrificada sem necessidade, com dor e sofrimento, por pura diversão e prazer dos caçadores. Exclui-se do raciocínio a caça para a finalidade de subsistência alimentar.

\footnotetext{
35 SALLES, Alvaro Angelo. Uma bioética e hipotética petição inicial: subsídios para a caracterização do animal como pessoa física não humana no direito brasileiro. In: BIZAWU, Sébastien Kiwongui (org.). Direito dos Animais: desafios e perspectivas da proteção internacional. Belo Horizonte: Arraes Editores, 2015, p. 91-116.

36 SINGER, Peter. Practical Ethics. Third Edition. New York: Cambridge University Press, 2011, p. 119-120.
} 
Nesse sentido, a melhor interpretação no paradigma do Estado Socioambiental de Direito seria a previsão da caça apenas para à obtenção de alimentos.

Para fins de comparação, observa-se que a Declaração Universal dos Direitos dos Animais ${ }^{37}$ estabelece o biocídio, a morte de um animal sem necessidade, um crime contra a vida. Do mesmo modo, veda a caça por diversão ou por esporte, prevendo, contudo, a possibilidade de morte de um animal, em razão da caça ou por outro motivo, apenas quando o grau de necessidade ultrapassar proporcionalmente as demais normas de proteção a vida animal.

\section{A DESCOISIFICAÇÃO dOS ANIMAIS: O PROJETO DE LEI DO SENADO $315 / 2015$}

Em 2015, o Senador pelo estado de Minas Gerais, Antônio Anastasia, apresentou um projeto de lei (PLS 315/2015) que altera o Código Civil brasileiro, acrescentando parágrafo único ao seu artigo 82 e uma nova alteração ao inciso IV, do artigo $83^{38}$. O projeto em questão tem como objetivo a alteração do sistema jurídico brasileiro para descoisificar os animais:

\footnotetext{
Acrescenta parágrafo único ao art.82, e inciso IV ao art. 83 da Lei $\mathrm{n}^{\circ} 10.406$, de 10 de janeiro de 2002 (Código Civil), para que determinar que os animais não serão considerados coisas.

O CONGRESSO NACIONAL decreta:

Art. $1^{\circ}$. Os arts. 82 e 83 da Lei $n^{\circ} 10.406$, de 10 de janeiro de 2002 - Código Civil, passam a vigorar com as seguintes redações:

"Art. 82..

serão considerados coisas. Art.83 .............................

disposto em lei especial." (NR)

Art. $2^{\circ}$. Esta lei entrará em vigor na data de sua publicação.
}

Ao comentar a iniciativa, a Presidente da Comissão dos Direitos dos Animais da $\mathrm{OAB} / \mathrm{MG}$, Edna Cardozo Dias ${ }^{39}$, anota ser esse um projeto de vanguarda, alterando o Código Civil brasileiro para considerar os animais bens, quando não houver lei especial disciplinando o contrário. Salienta que vários países europeus já fizeram a mudança do status jurídicos dos animais em seus códigos civis:

\footnotetext{
37 Disponível em: <http://bit.ly/1fAN4Mo> Acesso em: 10 ago. 2015.

38 BRASIL. SENADO FEDERAL. Projeto de Lei do Senado - PLS 315/2015. Acrescenta parágrafo único ao art.82, e inciso IV ao art. 83 da Lei n ${ }^{\circ}$ 10.406, de 10 de janeiro de 2002 (Código Civil), para que determinar que os animais não serão considerados coisas. Disponível em: 〈http://bit.ly/1KG9bK5> Acesso em: 10 ago. 2015.

39 DIAS, Edna Cardoso. Os animais e seus direitos. Disponível em: 〈http://bit.ly/1PLeT1R〉 Acesso em: 10 ago. 2015.
} 
Os países pioneiros na alteração da natureza jurídica dos animais são a Suíça (desde 2002), a Alemanha (desde 1990), a Áustria (desde 1988) e a França (desde janeiro de 2015). Os três primeiros fazem constar em seu Código Civil que os animais não são coisas ou objetos, e só se aplica o regime jurídico de bens quando não houver leis específicas. O Código Civil francês reconhece os animais como seres sensíveis, mas admite aplicação do regime jurídico de bens se não houver lei específica dispondo em contrário.

Esclarece Edna Dias ${ }^{40}$ que a opção seguida no Projeto de Lei do Senado 315/2015 foi a do modelo alemão, tendo em vista que no Brasil, "coisa” está relacionada, juridicamente, à ideia de utilidade patrimonial, enquanto que "bem" se relaciona a direitos, sem necessariamente conteúdo econômico.

De fato, na justificativa do PLS 315/2015 pode-se verificar a opção pelo direito alemão: "Preferimos, na linha do Direito alemão, identificar a coisa sob o aspecto de sua materialidade, reservando o vocábulo aos objetos corpóreos. Os bens, por sua vez, compreenderiam os objetos corpóreos ou materiais (coisas) e os ideais (bens imateriais)." ${ }^{41}$

Após esclarecer que no Brasil, os "animais silvestres são considerados bens de uso comum do povo e bens públicos pela Constituição da República, os domésticos, de acordo com o Código Civil, são considerados bens móveis/coisas. ${ }^{` 42}$, Edna Cardoso Dias defende a mudança de categoria no status jurídico dos animais no Código Civil como urgente e necessária, por merecerem a proteção especial como seres sencientes:

Por razões de coerência e em respeito ao princípio da proporcionalidade e mantendose a devida distância dos seres humanos na hierarquia de valores, uma mudança da categoria no status jurídico dos animais no Código Civil é necessária e urgente.

Não podemos deixar o Brasil fora dessa grande revolução teórica que já chegou aos países adiantados em relação ao status jurídico do animal. Os animais, ainda que continuem a ser classificados como bens, merecem uma proteção especial em relação às outras espécies de bens, uma vez que a ciência os reconhece como seres vivos sensíveis. $^{43}$

A alteração do Código Civil frances é destacada na justificativa do PLS 315/2015 por ter sido a última a ser registrada, em 28 de janeiro de 2015, e por ter sido a alteração mais expressiva, embora não seguida no projeto brasileiro, ao prever uma proteção afirmativa,

\footnotetext{
40 Ibidem.

41 BRASIL. SENADO FEDERAL. Projeto de Lei do Senado PLS 315/2015. Acrescenta parágrafo único ao art.82, e inciso IV ao art. 83 da Lei $\mathrm{n}^{\circ}$ 10.406, de 10 de janeiro de 2002 (Código Civil), para que determinar que os animais não serão considerados coisas. Disponível em: <http://bit.ly/1KG9bK5> Acesso em: 10 ago. 2015.

42 DIAS, Edna Cardoso. Os animais e seus direitos. Disponível em: <http://bit.ly/1PLeT1R> Acesso em: 10 ago. 2015.

43 Ibidem.
} 
reconhecendo que os animais são dotados de sensibilidade. ${ }^{44}$

Deveras, o Código Civil francês foi alterado em fevereiro de 2015, pela Lei 2015$177^{45}$, que inseriu o artigo $515-14^{46}$ prevendo que : "Os animais são seres vivos dotados de sensibilidade. Sujeitos as leis que os protegem, os animais são submetidos ao regime de bens" ${ }^{\prime 47}$ (tradução nossa).

A alteração no Código Civil francês foi provocada por um requerimento da organização não governamental francesa Fondation 30 Milion Amis, conforme noticiou a Radio France Internationale ${ }^{48}$. “A modificação na lei foi motivada por uma petição lançada há dois anos por uma fundação francesa de proteção aos animais, conhecida como "30 Milhões de Amigos.". Na mesma reportagem a Radio France Internationale informa que apesar da vitória, a Fondation 30 Milion Amis lamentou que uma categoria jurídica específica para os animais não tenha sido criada: “A própria Fundação 30 Milhões de Amigos, que lançou a petição, lamenta que uma categoria à parte não tenha sido criada. “

O Código Civil Alemão (BGB) ${ }^{49}$, citada na justificativa do PLS 315/2015 e modelo para o projeto brasileiro, na sua Seção 90a (\$90a) trata os animais como “coisas" seguindo a concepção adotada na Seção 90 (§90) de que somente objetos corporificados ou materiais são “coisas" 50 (tradução nossa):

\section{Seção 90 - Conceito de coisa}

Apenas objetos corpóreos são coisas como definidas por lei.

Seção 90a - Animais

Os animais não são coisas. Eles são protegidos por leis especiais. Eles são regidos pelas disposições que se aplicam às coisas, com as modificações necessárias, exceto nos casos previstos em contrário.

O Código Civil Suiço ${ }^{51}$, também citado na justificativa do PLS 315/2015, foi alterado

\footnotetext{
44 BRASIL. SENADO FEDERAL. Projeto de Lei do Senado PLS 315/2015. Acrescenta parágrafo único ao art.82, e inciso IV ao art. 83 da Lei $n^{\circ}$ 10.406, de 10 de janeiro de 2002 (Código Civil), para que determinar que os animais não serão considerados coisas. Disponível em: <http://bit.ly/1KG9bK5> Acesso em: 10 ago. 2015.

45 FRANÇA. Loi 2015-177. Disponível em: 〈http://bit.ly/1hUPfwj> Acesso em: 10 ago. 2015.

46 FRANÇA. Code Civil. Article 515-14. Disponível em: 〈http://bit.ly/1NE28a8> Acesso em: 10 ago. 2015.

47 Les animaux sont des êtres vivants doués de sensibilité. Sous réserve des lois qui les protègent, les animaux sont soumis au régime des biens.

${ }^{48}$ Radio France Internationale. Mudança no Código Civil francês considera animais "seres sensíveis". Disponível em: <http://bit.ly/1I6oREs> Acesso em: 10 ago. 2015.

${ }^{49}$ ALEMANHA. GERMAN LAW ARCHIVE. Civil Code / BGB - modernized. Disponível em: 〈http://bit.ly/1JepKg5> Acesso em: 10 ago. 2015.

${ }^{50}$ Section 90 Concept of the thing. Only corporeal objects are things as defined by law. Section 90a Animals. Animals are not things. They are protected by special statutes. They are governed by the provisions that apply to things, with the necessary modifications, except insofar as otherwise provided.

${ }^{51}$ SUIÇA. Federal Act on the Amendment of the Swiss Civil Code. Disponível em: 〈http://bit.ly/1Pu9dIQ〉 Acesso em: 10 ago. 2015.
} 
em 2002 para dipor que os animais não são objetos: “Art. 641a. Animais não são objetos. Quando não houver disposição especial para os animais, eles estão sujeitos as disposições que regem os objetos." ${ }^{, 52}$ (tradução nossa)

Observa-se que o Código Civil Suíço trata os animais como “objetos”, não fazendo a distinção entre "coisa" e "bem", como prevê o Código Civil Alemão.

O PLS 315/2015 foi objeto de parecer exarado pelo Senador Alvaro Dias, do qual se destaca, quanto ao mérito do projeto, o trecho abaixo, por representar a recepção da fundamentalidade do direito ao meio ambiente ecologicamente equilibrado, da ambientalização do direito brasileiro e da ideia de efetiva proteção ambiental ${ }^{53}$ :

\begin{abstract}
No que concerne ao mérito da proposta, podemos afirmar que, com o advento da Constituição Federal de 1988, o respeito ao meio ambiente foi elevado ao status de direito fundamental, em seu art. 225. A proteção e defesa dos animais, bem como a vedação à crueldade, são expressamente previstas em seu $\S 1^{\circ}$, inciso VII, ao prescrever como incumbência do Poder Público a proteção da fauna e da flora, vedadas, na forma da lei, as práticas que coloquem em risco sua função ecológica, provoquem a extinção das espécies ou submetam os animais a crueldade. Importa destacar, do capítulo constitucional que trata da proteção ambiental, o $\S 3^{\circ}$ do art. 225 , por instituir a responsabilidade civil, penal e administrativa às condutas e atividades consideradas lesivas ao meio ambiente.
\end{abstract}

No parecer também é destacado que o PLS 315/2015 rompe a antiga dogmática civilista, observando o inegável "dever da da coletividade e do Poder Público em defender e proteger os animais, haja vista os dispositivos constitucionais que vedam a crueldade contra estes seres vivos, e o de ampliação dessas garantias constitucionais. “54

De fato, como observa Gary L. Francione ${ }^{55}$, a visão de que os animais são coisas é antiga e até o século XIX não prosperaria qualquer debate sobre a utilização dos animais e sobre a existência de uma obrigação moral dos homens para com eles. Relembra o autor que René Descartes, considerado o fundador da filosofia moderna, afirmava que os animais eram máquinas em movimento, sem sentimentos, sem racionalidade, sem alma.

O PLS 315/2015, caso aprovado, romperá também no Brasil, a secular tradição civilista que compreende os animais como "coisas". Essa descoisificação poderá ser o

\footnotetext{
52 Art. 641A - 1 Animals are not objects. 2 Where no special provisions exist for animals, they are subject to the provisions governing objects. 53 BRASIL. SENADO FEDERAL. Parecer da Comissão de Constituição, Justiça e Cidadania sobre Projeto de Lei do Senado (PLS) $\mathbf{n}^{\circ}$ 351, de 2015. Disponível em: 〈http://bit.ly/1K9PUFd> Acesso em: 10 ago. 2015.

54 BRASIL. SENADO FEDERAL. Parecer da Comissão de Constituição, Justiça e Cidadania sobre Projeto de Lei do Senado (PLS) $\mathbf{n}^{\circ}$ 351, de 2015. Disponível em: 〈http://bit.ly/1K9PUFd> Acesso em: 10 ago. 2015.

55 FRANCIONE, Gary L. Animals-property or persons ? In: SUNSTEIN, Cass R.; NUSSBAUM, Martha C. (orgs.). Animal Rights: Current Debates and New Directions. New York: Oxford University Press, 2004, p. 110-111.
} 
primeiro passo para o reconhecimento de que os animais tem sentimentos, a exemplo da alteração sofrida pelo Código Civil Francês, e para que, em um processo contínuo de debates e alterações legislativas, os animais sejam reconhecidos como titulares de direitos.

\section{CONCLUSÃO}

A partir da Constituição de 1988, denominada de "Constituição verde", "Constituição ecológica”, entre outras denominações, o sistema jurídico brasileiro é ambientalizado e o próprio Estado brasileiro sofre uma mutação para um Estado Sociambiental de Direito.

Nesse paradigma socioambiental, as regras de proteção ambiental para as atuais e futuras gerações devem ser compreendidas e aplicadas com a máxima efetividade.

Embora a Constituição vede o tratamento cruel aos animais e o manejo que possa levar a sua extinção, não é expressa na descoisificação dos animais, que continuam na legislação infraconstitucional a serem considerados coisas.

Tendo em vista o paradigma do Estado Sociombiental de Direito, com o mandamento da máxima proteção ambiental, essa coisificação dos animais deve ser revista.

O Projeto de Lei do Senado 315/2015 inova na ordem jurídica brasileira ao prever a descoisificação dos animais. A proposta rompe dogmas civilistas seculares, seguindo algumas codificação civis estrangeiras, como a alemã, a suíça, a austríaca e a francesa.

O PLS 315/2015, apesar de se constituir em grande avanço e inovação jurídica, não atende completamente a nova ordem jurídica ambientalizada já que se limita a prever que os animais não são coisas, sem criar uma categoria jurídica própria, sem reconhecer que eles tem sentimentos, que podem sentir dor e que por essas razões merecem um tratamento jurídico específico. 


\section{REFERÊNCIAS}

ALEMANHA. GERMAN LAW ARCHIVE. Civil Code / BGB - modernized. Disponível em: <http://bit.ly/1JepKg5> Acesso em: 10 ago. 2015.

AYALA, Patrick de Araújo. Constitucionalização do ambiente e ecologização da Constituição brasileira. In: CANOTILHO, José Joaquim Gomes, LEITE, José Rubens Morato (orgs.). Direito Constitucional Ambiental Brasileiro. 5. ed. São Paulo: Saraiva, 2012.

BENJAMIN, Antônio Herman. Constitucionalização do ambiente e ecologização da constituição brasileira. In: CANOTILHO, J.J. Gomes; LEITE, José R. Morato (org.). Direito Constitucional Ambiental Brasileiro. 5a ed. São Paulo: Saraiva, 2012.

BORTOLINI, Rafaela Emilia; AYALA, Patryck de Araújo. In: PADILHA, Norma Sueli; FIORILLO, Celso Antonio Pacheco; CAMPELLO, Livia Gaigher Bosio (orgs.). Direito ambiental I. Florianópolis: FUNJAB, 2013. Disponível em: 〈http://bit.ly/1U8tmWf> Acesso em: 01 ago. 2015.

BRASIL, Supremo Tribunal Federal. Ação Direta de Inconstitucionalidade 4029. Rel. Min. Luiz Fux, j. 08.03.2012, Dje 26.06.2012. Disponível em: <http://bit.ly/1uuuCdA> Acesso em: 16 ago. 2015.

BRASIL, Supremo Tribunal Federal. Agravo Regimental no Recurso Extraordinário RE 796347. Rel. Min. Celso de Mello, j. 24.03.2015, Dje 13.05.2015. Disponível em: <http://bit.ly/1hBEDT8> Acesso em: 01 ago. 2015.

BRASIL. Constituição (1988). Constituição da República Federativa do Brasil, 1988. Disponível em: <http://bit.ly/ZChEh1> Acesso em: 17 ago. 2015.

BRASIL. Lei n. 10.406, de 10 de janeiro de 2002. Insitui o Código Civil. Disponível em: <http://bit.ly/1drzx5j> Acesso em: 10 ago. 2015.

BRASIL. Lei n. 9.605, de 12 de fevereiro de 1998. Dispõe sobre as sanções penais e administrativas derivadas de condutas e atividades lesivas ao meio ambiente, e dá outras providências. Disponível em: <http://bit.ly/1L6oaCf> Acesso em: 10 ago. 2015.

BRASIL. SENADO FEDERAL. Parecer da Comissão de Constituição, Justiça e Cidadania sobre Projeto de Lei do Senado (PLS) $\mathbf{n}^{\mathbf{0}}$ 351, de 2015. Disponível em: <http://bit.ly/1K9PUFd> Acesso em: 10 ago. 2015.

BRASIL. SENADO FEDERAL. Projeto de Lei do Senado PLS 315/2015. Acrescenta parágrafo único ao art.82, e inciso IV ao art. 83 da Lei ${ }^{\circ} 10.406$, de 10 de janeiro de 2002 (Código Civil), para que determinar que os animais não serão considerados coisas. Disponível em: <http://bit.ly/1KG9bK5> Acesso em: 10 ago. 2015.

DIAS, Edna Cardozo. Teoria dos Direitos dos Animais. In: BIZAWU, Sébastien Kiwongui (org.). Direito dos Animais: desafios e perspectivas da proteção internacional. Belo Horizonte: Arraes Editores, 2015. 
DIAS, Edna Cardoso. Os animais e seus direitos. Disponível em: 〈http://bit.ly/1PLeT1R> Acesso em: 10 ago. 2015.

FERREIRA, Heline Sivini Ferreira; LEITE, José Rubens Morato. A expressão dos objetivos do estado de direito ambiental na Constituição Federal de 1988. In: LEITE, José Rubens Morato; FERREIRA, Heline Sivini; CAETANO, Matheus Almeida (orgs.). Repensando o estado de direito ambiental. Florianópolis: Fundação Boiteux, 2012.

FRANÇA. Code Civil. Article 515-14. Disponível em: 〈http://bit.ly/1NE28a8> Acesso em: 10 ago. 2015.

FRANÇA. Loi 2015-177. Disponível em: <http://bit.ly/1hUPfwj> Acesso em: 10 ago. 2015.

FRANCIONE, Gary L. Animals-property or persons ? In: SUNSTEIN, Cass R.; NUSSBAUM, Martha C. (orgs.). Animal Rights: Current Debates and New Directions. New York: Oxford University Press, 2004..

HUPFFER, Haide Maria; NAIME, Roberto. Vocação de diálogo do artigo 225 da Constituição Federal no conflito ambiental. In: Revista veredas do direito. Belo Horizonte: Escola Superior Dom Helder Câmara, v. 9, n. 17, 2012. Disponível em: 〈http://bit.ly/1zspeHN> Acesso em: 16 ago. 2015.

LEITE, José Rubens Morato; AYALA, Patryck de Araújo. Dano ambiental: do individual ao coletivo extrapatrimonial: teoria e prática. 5. ed. São Paulo: Editora Revista dos Tribunais, 2011.

LEITE, José Rubens Morato; CAETANO, Matheus Almeida. Breves reflexões sobre os elementos do estado de direito ambiental brasileiro. In: LEITE, José Rubens Morato; FERREIRA, Heline Sivini; CAETANO, Matheus Almeida (orgs.). Repensando o estado de direito ambiental. Florianópolis: Fundação Boiteux, 2012.

MILARÉ, Édis, Direito do ambiente: a gestão ambiental em foco: doutrina, jurisprudência, glossário. 7. ed. São Paulo: Editora Revista dos Tribunais, 2011.

PADILHA, Norma Sueli. O Compromisso Constitucional Brasileiro com a Sustentabilidade Ambiental. Disponível em: <http://bit.ly/1pBxstd> Acesso em: 01 ago. 2015 .

PADILHA, Norma Sueli. Fundamentos constitucionais do direito ambiental brasileiro. Rio de Janeiro: Elsevier, 2010.

Radio France Internationale. Mudança no Código Civil francês considera animais "seres sensíveis". Disponível em: 〈http://bit.ly/1I6oREs> Acesso em: 10 ago. 2015.

RIBEIRO, Luiz Gustavo Gonçalves; MACHADO JÚNIOR, José Carlos. A ambientalização do direito penal: a tutela do ambiente pela terceira via. In: CUNHA, Belinda Pereira da; ALBURQUEQUE, Letícia; SOUZA, Leonardo da Rocha de (coords.) Direito ambiental III. Florianópolis: FUNJAB, 2014. Disponível em: <http://bit.ly/1x8iPCk> Acesso em: 16 ago. 2015. 
SALLES, Alvaro Angelo. Uma bioética e hipotética petição inicial: subsídios para a caracterização do animal como pessoa física não humana no direito brasileiro. In: BIZAWU, Sébastien Kiwongui (org.). Direito dos Animais: desafios e perspectivas da proteção internacional. Belo Horizonte: Arraes Editores, 2015.

SILVA, José Afonso da. Fundamentos constitucionais da proteção ambiental. In: DAIBERT, Arlindo (org). Direito Ambiental Comparado. Belo Horizonte: Fórum, 2008.

SINGER, Peter. Practical Ethics. third edition. New York: Cambridge University Press. 2011.

SOARES Junior, Jarbas (Cord); ALVARENGA, Luciano José (Cord); SAMPAIO, José Adércio Leite, Direito Ambiental no STJ, Belo Horizonte: Del Rey, 2010.

SUIÇA. Federal Act on the Amendment of the Swiss Civil Code. Disponível em: <http://bit.ly/1Pu9dIQ> Acesso em: 10 ago. 2015.

STACZUK, Bruno Laskowski; FERREIRA, Heline Sivini. A dimensão social do estado de direito Ambiental. In: LEITE, José Rubens Morato; FERREIRA, Heline Sivini; CAETANO, Matheus Almeida (org). Repensando o estado de direito ambiental. Florianópolis: Fundação Boiteux, 2012.

THOMÉ, Romeu. O princípio da vedação de retrocesso socioambiental no contexto da sociedade de risco. Salvador: Juspodivm, 2014. 